\title{
Table of Contents
}

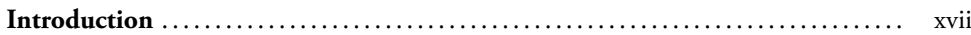

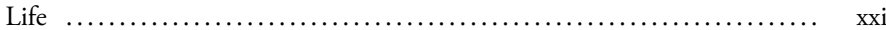

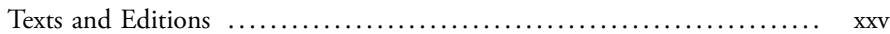

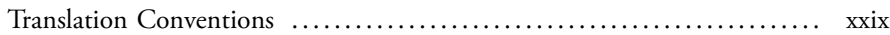

Book 1

Pentametric Old-Style Verse

1.1 畓香山湛上人 Seeking His Eminence Zhan, on Incense

Mountain ................................ 2

1.2 雲門寺西六七里 Hearing of the Deep Seclusion of the Aranya

聞符公蘭若幽與 of Sir Fu, Six or Seven $l i$ West of Cloud Gate

薛入同往

Temple, I Go There with Xue (Eight) $\ldots \ldots \ldots \ldots \ldots \quad 4$

1.3 宿天台桐柏觀

1.4 宿終南翠微寺

1.5 春初漢中漾舟

1.6 宿來公山房期丁 大不至

1.7 耶溪泛舟

Passing the Night at Tongbo Abbey on Tiantai .... 6

Passing the Night at Cuiwei Temple on

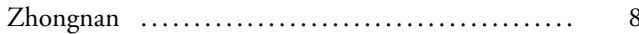

Afloat on the Han at the Start of Springtime ..... 10

Passing the Night at Sir Lai's Mountain Chamber

where I was to Meet with Ding (Eldest), who Does

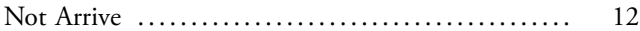

Boating on Ye Brook ........................ 12

1.8 彭掻湖中望盧山 On Lake Pengli, Gazing Off at Mount Lu ....... 14

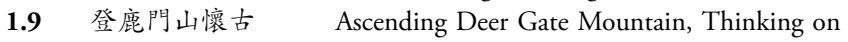

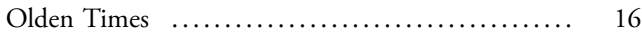

1.10 遊明禪師西山蘭若 A Visit to the West Mountain Aranya of

Meditation Master Ming $\ldots . . \ldots \ldots \ldots \ldots \ldots \ldots . \ldots 18$

1.11 㯖鄭五愔彈琴

1.12 疾愈過龍泉寺精

Listening to Zheng (Five) Yin Play the Zither .... 20

舍呈易業二上人 Spring Temple, Place of Pure Concentration; To

Show to the Two Eminences Yi and Ye ......... 22

1.13 湖中旅泊寄閻九

A Travel-Mooring by the Lake; Sent to Yan (Nine)

司户 of the Finance Bureau .......................... 24

1.14 大堤行寄萬七

1.15 還山贈湛禪師

A Great Dyke Ballad; Sent to Wan (Seven) ........

Returning to the Mountains; For Meditation

Master Zhan

1.16 秋登萬山寄張五

Ascending Mount Wan in Autumn; Sent to Zhang (Five)

1.17 登江中孤嶼贈王

Climbing the Solitary Isle in the River; For Wang 白雲先生迥

Jiong, Monsignor of White Clouds

1.18 晚春臥疾寄張入 子容

Lying Ill in Late Springtime; Sent to Zhang (Eight) 
1.19 書懷貽京邑故人 Writing My Heart-held Thoughts; To Present to an Old Friend in the Capital District ...............

1.20 遊雲門寺寄越府 A Visit to Cloud Gate Temple; Sent to Finance 包户曹徐起居

Officer Bao and Diarist $\mathrm{Xu}$ of the Yue

Administration

1.21 示孟郊

1.22 山中逢道士雲公

For Showing to Meng Jiao

Happening on the Daoist Adept, Lordship Yun, in

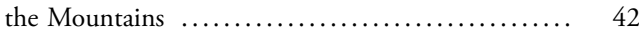

1.23 歲暮海上作

Written by the Sea at the Year's Waning ......... 46

1.24 越中逢天台太一子 In Yue, Happening on the Tiantai Master of Greatest Unity

1.25 自浔陽泛舟經明

Composed as My Boat Crosses Bright Lake from 海作

1.26 早發漁浦潭

1.27 經七里灘

1.28 南陽北阻雪

1.29 將適天台留別臨 Xunyang 50

Setting Out Early from the Tarn at Fisher's Cove $\quad . . \quad 52$

Passing Through Seven-League Rapids .......... 52

Blocked by Snow North of Nanyang ........... 56

安李主簿

Shortly on the Way to Tiantai, I Leave this at

Parting for Li, Chief Registrar of Lin'an

1.30 適越留別譙縣張

On the Way to Yue, I Leave this at Parting for 主簿申屠少府

1.31 送從弟邑下第後 Chief Registrar Zhang and Constable Shentu of Qiao District 歸會嵇

Seeing Off Paternal Cousin Yong, Returning to Kuaiji after Failing the Exam $\ldots . \ldots \ldots \ldots \ldots \ldots .60$

1.32 送辛大不及

1.33 江上別流人

1.34 洗然弟竹亭 Seeing Off Xin (Eldest), but I Was Not in Time .. 62 Parting at Riverside from Someone in Penal Exile .. 64 The Bamboo Pavilion of my Younger Brother Xianran

1.35 夜登孔伯昭南樓時 沈太清朱㫒在座

Climbing at Night to the Upper Storey of Kong Bozhao's South Loft-Building, When Shen Taiqing and Zhu Sheng were Present $\ldots \ldots \ldots \ldots \ldots \ldots \ldots .66$

1.36 宴包二宅

A Fête at the Residence of Bao (Two)

1.37 峴潭作

1.38 齒坐呈山南諸隱

Composed by the Tarn at Xian Mountain

At Chi's Old Site; To Show to Several Recluses

South of the Mountain

1.39 與王昌龄宴王道 A Fête at the Dwelling of the Daoist Adept Wang, 士房

1.40 襄陽公宅飲

1.41 同張明府清鏡嗼 with Wang Changling ...................... 72

Drinking at the Official Residence in Xiangyang .. 74

To Go with Magistrate Zhang's "Sighing Over a Mirror of Clarity"

1.42 夏日南亭懷辛大 On a Summer's Day at South Pavilion, Thinking of Xin (Eldest)

1.43 秋宵月下有懷

Heart-held Thoughts on an Autumn Night under the Moon .................................

1.44 仲夏歸南園寄京 Returning to South Garden in the Mid-Month of 邑舊遊

Summer; Sent to Former Associates in the Capital Precincts 
1.45 家園臥疾畢太祝 As I Lie Ill at my Home Garden, Grand Invocator 曜見䚄

Bi Yao Comes to Find Me $\ldots \ldots \ldots \ldots \ldots \ldots \ldots . \ldots 2$

1.46 田家元日 New Year's Day for the Farmers ............... 8

1.47 晚泊浔陽望香鏬峰 Mooring at Night in Xunyang, Gazing at Incense

Burner Peak ............................ 84

1.48 萬山潭

1.49 入峽寄弟

The Tarn at Mount Wan $\ldots \ldots \ldots \ldots \ldots \ldots \ldots . . \ldots 6$

Entering the Gorges; Sent to my Younger

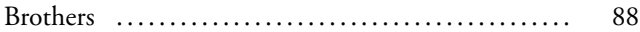

1.50 宿揚子津寄潤州 Passing the Night at the Yangzi Ford; Sent to 長山劉隱士 Recluse Liu of Changshan in Runzhou

1.51 送丁大鳳進士赴舉 Seeing Off Ding Feng (Eldest), En Route as a

Candidate for the Exam $\ldots . . . \ldots \ldots \ldots \ldots \ldots . . . \ldots 90$

1.52 送吴悦遊韶陽

Seeing Off Wu Yue Traveling to Shaoyang ....... 92

1.53 送堜七赴西軍

Seeing Off Chen (Seven) On his Way to the

Armies in the West $\ldots \ldots \ldots \ldots \ldots \ldots \ldots \ldots \ldots . .64$

1.54 田園作等 Composed in Field and Garden ................ 94

1.55 從張丞相遊紀南城 Following after Prime Minister Zhang on a

獵戲贈裴迥張參軍 Hunting Excursion to Jinancheng; In Fun for

Pei Jiong and Aide-de-Camp Zhang $\ldots \ldots \ldots \ldots \ldots .98$

1.56 登望楚山最高頂 Ascending the Highest Crest of Mount Gazing-at-

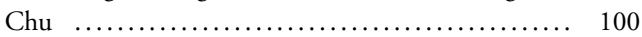

1.57 採樵作 Composed upon Gathering Firewood .......... 102

1.58 早梅 Early Prunus ........................... 102

1.59 澗南園即事貽皎 At the Garden South of the Branch, On a Chance 上人 Theme; To Present to His Eminence Jiao ........ 104

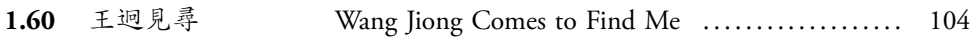

1.61 與黄侍御北津泛舟 Boating at North Ford, with Imperial Censor

1.62 題長安主人壁 Inscribed on a Wall of my Host's in Chang'an .... 108

1.63 庭橘 Courtyard Tangerines ..................... 110

Book 2

Heptametric Old-Style Verse

2.1 夜歸庇門歌 Song on Returning at Night to Deer Gate .......

2.2 和盧明府送鄭十 Matching Magistrate Lu’s Poem “Seeing Off Zheng

三還京兼寄之 (Thirteen) Returning to the Capital”; Sent along

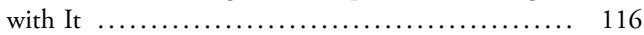

2.3 送王七尉松滋得 Seeing Off Wang (Seven) to be Constable of

陽臺雲 Songzi; I Drew the Tag “Clouds of the Sunlit

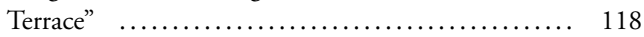

2.4 贸鳥鵡洲送王九遊Ａt Parrot Isle, Seeing Off Wang (Nine) Traveling

江左

East of the Jiang $\ldots \ldots \ldots \ldots \ldots \ldots \ldots \ldots \ldots \ldots \ldots, 120$

2.5 高陽池送朱二 At Gaoyang Pool, Seeing Off Zhu (Two) ......... 122 


\section{Pentametric Regulated Couplets in Series}

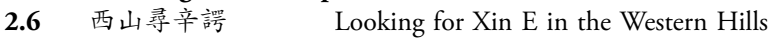

2.7 冬至後過吴張二子 After the Advent of Winter, I Stop by the 檀溪別業

Detached Manors of the Two Men, Wu and

Zhang, Near to Sandalwood Stream

2.8 陪張丞相自松滋江 Accompanying Chief Minister Zhang Eastward on 東泊渚宫 the River from Songzi, to Moor by the Palace on the Holm

2.9 陪盧明府泛舟洄峴 Composed while Accompanying Magistrate Lu, 山作

Drifting a Boat Back to Mount Xian

2.10 陪張丞相祠紫蓋 山途經玉泉寺

2.11 臘月八日於剡縣 Accompanying Chief Minister Zhang to Offer Cult at Purple Canopy Mountain, Passing Jade Fountain Temple on the Route 石城寺禮拜

On the Eighth Day of All-Hallows Month,

Worshipping at Stone Citadel Temple in Shan

District

2.12 同獨孤使君東齋作

To Go With Prefect Dugu's Poem "Composed at My East Study"

2.13 峴山送朱大去非 遊巴東

At Mt. Xian Seeing Off Zhu Qufei (Eldest)

2.14 宴張記室宅

2.15 登龍興寺閣

Traveling to Badong

A Fête at Secretary Zhang's Residence $\ldots . . . \ldots \ldots . \quad 142$

Climbing the Gallery of the Dragon Ascendant

Temple ............................... 144

2.16 登總持寺浮屠

2.17 與崔二十一遊鏡

Climbing the Pagoda of the Dhāranī Temple ......

湖寄包賀二公

An Outing to Mirror Lake with Cui (Twenty-one);

Sent to the Two Gentlemen Bao and $\mathrm{He} \ldots \ldots \ldots . .148$

2.18 本闍黎新亭作

2.19 長安早春

2.20 秦中苦雨思歸贈 袁左丞賀侍郎

Written at the New Pavilion of the Ācārya of the Fundamentals ............................. 150

Early Springtime in Chang'an $\ldots . \ldots \ldots \ldots \ldots \ldots . . \ldots 152$

During Steady Rain in Qin I Long to Return Home; For Left Advisor Yuan and Vice-Director $\mathrm{He}$

2.21 陪張丞相登荆州城

Accompanying Chief Minister Zhang to a High 樓因寄薊州張使君 Loft on the Jingzhou City-Walls; This then Sent 及浪泊戍主劉家 to Prefect Zhang of Jizhou and Mr. Liu, Garrison Chief of Liangbo

2.22 荊門上張丞相

Offered Up to Chief Minister Zhang at Thorn Portal

2.23 和宋太史北樓新亭

Matching Grand Calendrist Song's Poem "The

North Loft's New Pavilion"

2.24 夜泊宣城界

Night-Mooring at the Border of Xuancheng

2.25 奉先張明府休沋 A Banquet Gathering at the Lake Pavilion of 還郷海亭宴集探 得堦字 Magistrate Zhang of Fengxian who Has Returned to his Homeplace on Official Leave; I Drew the Rhyme-Word "Stairs" ......................... 
2.26 同張明府碧谿贈答 To Go With the Poems of Bestowal and Response by Magistrate Zhang and "Blue Brook" ........ 166

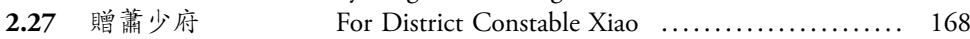

2.28 同王九題就師山房 To Go With Wang (Nine)'s “Inscribed at the Mountain Dwelling of Master Jiu" ........... 170

2.29 上張吏部 Offered Up to Zhang of the Board of Personnel .. 172

2.30 和于判官登萬山亭 Matching Evaluative Official Yu's Poem "Climbing 因贈洪府都督韓公 to the Pavilion on Mount Wan"; For Lordship

\subsection{1 下漖石}

Han, Governor-General of Hongfu 174

2.32 行至熯川作 Down the Gan Rock-race .................. 176

2.33 久滞越中贈謝南 Composed on Reaching the Han Watercourse .... 178 池會嵇賀少府 Long Detained in Yue; For Xie Nanchi and

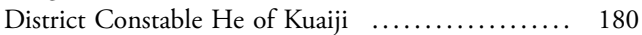

2.34 送韓使君除洪府 都督

2.35 盧明府九日峴山 宴袁使君張郎中 崔員外

Seeing Off Prefect Han, on His Appointment as Governor-General of Hongfu At Mt. Xian on Double-Ninth Day Magistrate Lu Fêtes Prefect Yuan, Director Zhang, and Vice-Director Cui

2.36 宴崔明府宅夜觀妓 A Fête at Magistrate Cui's Residence, Watching the

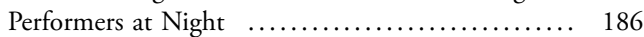

2.37 韓大使東濟會岳 A Gathering at Commissioner Han's East Studio 上人諸學士 for His Eminence Yue and Several Scholars .......

2.38 初年樂城舘中臥 疾懷歸 At the Start of the Year I Lie Ill at a Hostel in Lecheng, Longing to Go Home

上已日澗南園期王 At the Garden South of the Branch on the

2.39 上已日澗南園期王 Double-Third Day, Expecting the Hermit Wang, Chen (Seven), and Several Others, Who Do Not Arrive

2.40 送莫氏甥兼諸昆第 Seeing Off My Cousin of the Mo Clan who, 從韓司馬入西軍 Together with Several Brothers, is Following Marshal Han to Join the Western Armies .........

2.41 峴山送萧員外之 On Mount Xian, Seeing Off Vice-Director Xiao to 荆州 Jingzhou

2.42 送王昌齡之嶺南

Seeing Off Wang Changling to Lingnan

\section{Book 3}

\section{Pentametric Regulated Verse}

3.1 與諸子登峴山 Climbing Mount Xian in Company with Several Gentlemen ........................... 202

3.2臨洞庭 Looking Out on Dongting $\ldots \ldots \ldots \ldots \ldots \ldots \ldots . \ldots 204$

3.3 晚春

3.4 歲暮歸南山

Late Springtime ........................ 206

3.5 梅道上水亭

Returning to South Mountain at the Year's

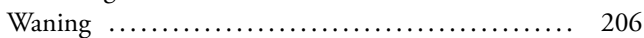
The Waterside Pavilion of the Daoist Adept Mei .. 208 
3.6 閑園懷蘇子

3.7 留別王維

3.8 武陵泛舟

3.9 同曹三御史行泛 湖歸越

3.10 遊景空寺蘭若

3.11 陪張丞相登當陽樓

3.12 與顔錢塘登樟亭 望潮作

3.13 大禹寺義公禪房

3.14 寻白鶴巏張子容 隱居

3.15 九日得新字

3.16 除夜樂城張少府宅

3.17 舟中曉望

3.18 遊精思觀迥王白 雲在後

3.19 與杭州薛司戶登 樟亭驛樓

3.20 寻天台山作

3.21 宿立公房

3.22 寻滕逸人故居

3.23 姚開府山池

3.24 夏日浮舟過滕逸 人別業

3.25 夏日辨玉法師茅齋

3.26 與張折衝遊者闍寺

3.27 與白明府遊江

3.28 遊精思題觀主山房

3.29 氷梅道士張山人

3.30 陪姚使君題惠上 人房得青字

3.31 晚春遠上人南亭
In My Idle Garden, Thinking Fondly of Master

$\mathrm{Su}$

To Leave Behind on Parting from Wang Wei ..... 210

Drifting a Boat in Wuling ................... 212

To Go With Censor Cao (Three)'s "Drifting on the Lake in Returning to Yue" ................. 214

An Outing to the Aranya by the Jingkong Temple 216

Accompanying Chief Minister Zhang on the

Dangyang Tower

Together with Yan of Qiantang, Composed on

Ascending Camphor Pavilion to Look Upon the

Tidal Bore

Lordship Yi's Meditation Chamber at the Temple of the Great Yu

Seeking Out Zhang Zirong's Recluse Dwelling on White Crane Cliff .............................

Double-Ninth Day; I Draw the Rhyme-word "New"

At District Constable Zhang's Residence in

Lecheng on New Year's Eve

Gazing Afar from the Boat at Daybreak

Returning from an Outing to the Jingsi Abbey,

with Wang "White Clouds" Behind Me ..........

Climbing the Loft-building of the Camphor

Pavilion Post-station, in Company with Xue of the

Finance Bureau of Hangzhou .................. 230

Composed upon Finding the Way to Tiantai ..... 232

Passing the Night at the Abode of Lordship Li ... 234

Searching Out the Former Residence of the

Unattached Person, Teng

At the Private Garden of Grand Dignitary Yao ... 238

Boating on a Summer's Day and Stopping at the

Detached Manor of the Unattached Person, Teng .. 240

A Summer's Day at the Thatched-roof Retreat of the Dharma Master Bianyu

An Outing to Grdhra Temple with Zhang of the Intrepid Militia

An Outing on the River with Magistrate Bo ..... 244

An Outing to the Jingsi Abbey; Inscribed at the

Abbot's Mountain Chamber

Seeking the Daoist Adept Mei and Hermit Zhang 248

Inscribed at the Chamber of His Eminence Hui, while Accompanying Prefect Yao; I Drew the Rhyme-word "Green"

Late Springtime, at the South Pavilion of His

Eminence Yuan 
3.32 人日登南陽驛門 亭子懷漢川諸友

3.33 遊鳳林寺西嶺

3.34 陪獨孤使君册與婣 員外誠登萬山亭

3.35 贈道士參廖

3.36 京還贈張維

3.37 題李十四庄兼贈 綦收校書

3.38 寄是正字

3.39 秋登張明府海亭

3.40 題融公蘭若

3.41 九日龍沙寄劉大

3.42 洞庭湖寄閻九

3.43 和李侍御渡松滋江

3.44 秦中感秋寄遠上人

3.45 重部李少府見贈

3.46 宿永嘉江寄山陰 崔國輔少府

3.47 上已日洛中寄王 迥九

3.48 聞裴侍御朏自襄 州司戶除豫州司 戶因以投寄

3.49 江上寄山陰崔國 輔少府

3.50 送洗然弟進士舉

3.51 夜泊盧江聞故人在 東林寺以詩寄之

3.52 宿桐盧江寄廣陵 舊遊

3.53 南還舟中寄袁太祝
On the Day of Humans, Ascending the Pavilion at the Nanyang Post-station Gate, and Thinking of Several Friends in Hanchuan $\ldots . \ldots \ldots \ldots \ldots \ldots . . .254$ An Outing to the Ridge West of Phoenix Grove Temple

Accompanying Prefect Dugu Ce and Vice-Director Xiao Cheng on Climbing to the Pavilion on Mount Wan ................................ 256

For the Daoist Adept Canliao $\ldots . . . \ldots \ldots \ldots \ldots . . \ldots 258$

Returning from the Capital; For Zhang Wei $\ldots . . .260$ Inscribed at the Farmstead of $\mathrm{Li}$ (Fourteen); Presented Also to Collator Qiwu ............... 262

Sent to Shi, Corrector of Texts .............. 264

Ascending the Lakeside Pavilion of Magistrate Zhang in Autumn ......................... 266 Inscribed at the Aranya of Lordship Rong ....... 268 At Dragon Sands on Double-Ninth Day; Sent to Liu (Eldest) .............................. 270

At Lake Dongting; Sent to Yan (Nine) ......... 272

Matching Attendant Censor Li's Poem "Crossing the Songzi River" ........................... 274

In Qin, Moved at Autumn; To Send to His

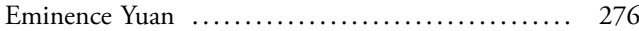

Replying Again to the Poem Presented to Me by Constable $\mathrm{Li}$................................

Passing the Night on the Yongjia River; To Send to Constable Cui Guofu of Shanyin $\ldots . \ldots \ldots \ldots \ldots \ldots .280$

On the Double-Third Day in Luo; To Send to

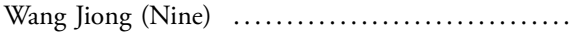

Having Heard that Imperial Censor Pei Fei is

Being Transferred from the Finance Bureau in Xiangzhou to the Finance Bureau in Yuzhou, I Consign this Poem to Send to Him ............. On the River; To Send to Constable Cui Guofu of

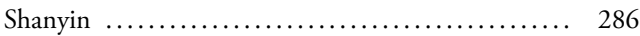

Seeing Off Younger Brother Xianran, for the Advanced Scholar Examination

While Mooring at Night on the Lu River, I Hear that an Old Friend is at the Eastern Grove Monastery, so Send Him this Poem Passing the Night on the Tonglu River; To Send to Former Acquaintances in Guangling ........... 292

On the Boat when Returning from the South; To Send to Grand Invocator Yuan 
3.54 東陂遇雨率雨貽 謝南池

3.55 行至汝墳寄盧徵君

3.56 寄天台道士

3.57 和張明府登鹿門山

3.58 和張三自穰縣還 途中遇雪

3.59 歲除夜會樂城張 少府宅

3.60 自洛之越

3.61 歸至趴中作

3.62 途中遇晴

3.63 蔡陽舘

3.64 他良七夕

3.65 夜泊牛渚趂薛入 船不及

3.66 曉入南山

3.67 夜渡湘水

3.68 赴京途中遇雪

3.69 宿武陵即事

3.70 同盧明府泾張郎 中除義王府司馬 海園作

3.71 落日望鄉

3.72 永嘉上浦舘逢張 入子容

3.73 送張子容赴舉

3.74 送張參明經舉兼 向㴚州省唓

3.75 泝江至武昌

3.76 唐城舘中早發寄 楊使君

3.77 陪李侍御謁聰上人

3.78 和張丞相春朝對雪
Encountering Rain on the Eastern Slope;

Impulsively Presented to Xie Nanchi

Upon Reaching Rufen on My Journey; Sent to

Summoned Gentleman Lu

Sent to a Daoist Adept on Mount Tiantai ........ 298

Matching Magistrate Zhang's Poem "Climbing

Deer Gate Mountain”

Matching Zhang (Three)'s Poem "Returning from

Rang District I'm Met with Snow on the Road" .. 302

A New Year's Eve Gathering in Lecheng at the

Residence of Constable Zhang ................. 304

Going from Luo to Yue ................... 306

Composed upon Reaching Ying while Returning

Home

Meeting with Clearing Skies on the Road ........ 308

At the Caiyang Hostel $\ldots \ldots \ldots \ldots \ldots \ldots \ldots \ldots \ldots . \quad 310$

In Another Countryside on Seventh Night ....... 312

Night-Mooring at Ox Isle, Hoping to Catch Up to

Xue (Eight)'s Boat, But I'm Not in Time ........ 314

Passing Into South Mountain at Daybreak ...... 316

Crossing Xiang River at Night ................ 318

Going to the Capital, Encountering Snow on the Way

Passing the Night in Wuling; On a Topic of the Moment .........................................

To Go With Magistrate Lu’s Poem "Composed at the Lake Garden, at a Farewell Banquet for Director Zhang Who is Appointed Martial Administrator for the Prince of Yi's Palatinate" .... Gazing Afar toward Home in the Setting Sun ..... At Shangpu Hostel in Yongjia, I Happen on Zhang (Eight) Zirong

Seeing Off Zhang Zirong On His Way to the

Examination

Seeing Off Zhang Shen for the Mingiing

Examination, Also to Pay Familial Respects in

Jingzhou

Going Up the River to Wuchang ............... 332

Starting Out Early from the Tangcheng Hostel;

Sent to Prefect Yang

Accompanying Censor $\mathrm{Li}$ on a Visit to $\mathrm{Hi}$

Eminence Cong 


\section{Book 4}

\section{Pentametric Regulated Verse}

4.1 送王宣從軍 Seeing Off Wang Xuan to Follow the Army ....... 340

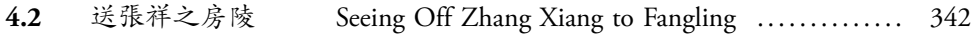

4.3 送桓子之趴城過禮 Seeing Off Master Huan to Yingcheng, for

Following Through with the Rites $\ldots \ldots \ldots \ldots \ldots \ldots .344$

4.4 早春潤州送弟還郷 Early Springtime in Runzhou; Seeing Off a

Younger Brother Returning to Our Homeland .... 346

4.5 送告八從軍

Seeing Off Gao (Eight) to Follow the Army ...... 348

4.6 送元公之鄂渚寻 Seeing Off Sir Yuan to Ezhu, Who is Seeking Out

觀主張駘彎

the Abbot Zhang Canluan .................. 350

4.7 峴山餞房琯崔宗之 A Farewell Feast at Mt. Xian for Fang Guan and

Cui Zongzhi ............................. 352

4.8送王五昆季省唓 Seeing Off Wang (Five), Older and Younger

4.10 送盧少府使入秦 Seeing Off District Constable Lu, Commissioned

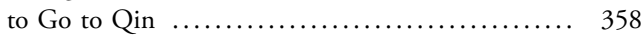

4.11 送謝錄事之越策 Seeing Off Intendant Xie to Yue ............... 358

4.12 洛下送奚三還掦州 By the Luo, Seeing Off Xi (Three) Returning to Yangzhou .............................. 360

4.13 送袁十嶺南尋弟 Seeing Off Yuan (Ten) to Find his Younger Brother South of the Ranges ...................... 362

4.14 永嘉別張子容 Parting from Zhang Zirong in Yongjia ........... 364

4.15 送袁太祝尉豫章 Seeing Off Grand Invocator Yuan to be District

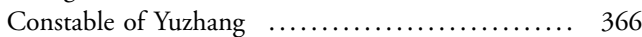

4.16 都下送辛大 At the Metropolis, Seeing Off Xin (Eldest) ...... 368

4.17 送席大 Seeing Off Xi (Eldest) $\ldots \ldots \ldots \ldots \ldots \ldots \ldots \ldots \ldots \ldots \ldots \ldots$

4.18 送頃界主簿之荆府 Seeing Off Chief Registrar Jia Bian to Jingfu ...... 372

4.19 送王大校書 Seeing Off Wang (Eldest), Collator of Texts ...... 374

4.20 浙江西上留別裴 Going Westward Up the Zhe River; I Leave this

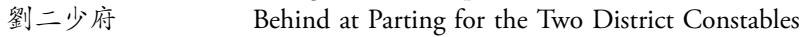

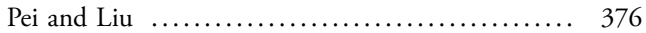

4.21 京還留別新豊諸友 Returning from the Capital; I Leave this Behind for Several Friends in Xinfeng .............. 378

4.22 廣陵別薛入

4.23 臨渙裴明府席遇 Parting from Xue (Eight) in Guangling $\ldots \ldots \ldots \ldots \quad 380$ 張十一房六 At District Magistrate Pei's Banquet in Linhuan, I Happen On Zhang (Eleven) and Fang (Six) ...... 382

4.24 盧明府早秋宴張郎 In Early Autumn District Magistrate Lu Gives a 中海園即事得秋字 Fête at the Lake Garden of Director Zhang; On the Spur of the Moment and Drawing the Rhymeword "Autumn"

4.25 同盧明府早秋夜 To Go With District Magistrate Lu's Poem "In 宴張郎中海亭 Early Autumn, an Evening Fête at the Lake Pavilion of Director Zhang" ................... 
4.26 崔明府宅夜觀妓

4.27 題第二山池

4.28 夏日宴衛明府宅 遇北使

4.29 清明日宴梅道士房

4.31 和貲主簿昇九日 登峴山

4.32 宴張別駕新齋

4.33 李氏園臥疾

4.34 過故人庄

4.35 途中九日懷襄陽

4.36 初出關旅亭夜坐 懷王大校書

4.37 李少府與王九再來

4.38 寻張五

4.39 張七及辛大見訪

4.40 題張野人園盧

4.41 過故融公蘭若

4.42 早寒江上有懷

4.43 南山下與老围期 種瓜

4.44 裴司士見訪

4.45 除夜

4.46 傷峴山雲表觀主

4.47 賦得盈盈棲上女

4.48 春怨

4.49 閨情

4.50 寒夜

4.51 美人分香
At District Magistrate Cui's Residence, Watching

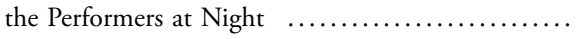
Inscribed at the Landscaped Hill and Pool of Rong (Two)

A Fête on a Summer's Day at the Residence of District Magistrate Wei, Meeting a Commissioner Going North

A Fête on Qingming Day at the Quarters of the Daoist Adept Mei

A Fête on Cold Food Day at the Residence of District Magistrate Zhang 396 Matching Chief Registrar Jia Bian's Poem "Ascending Mount Xian on Double-Ninth Day" .. 398 A Fête at Executive Aide Zhang's New Study ..... 400 Lying Ill at Mr. Li's Garden ................. 402 Stopping by an Old Friend's Farmstead ........ 404 On the Road on Double-Ninth Day, Yearning for Xiangyang

On First Going Out the Pass, I Sit Up at Night in a Travelers' Inn, Thinking Fondly of Collator Wang (Eldest)

District Constable Li Comes Once More with

Wang (Nine) $\ldots \ldots \ldots \ldots \ldots \ldots \ldots \ldots \ldots \ldots \ldots, 410$

Seeking Zhang (Five) $\ldots \ldots \ldots \ldots \ldots \ldots \ldots \ldots . \ldots . \ldots 12$

Zhang (Seven) and Xin (Eldest) Pay Me a Visit ... 414

Inscribed at the Garden Cottage of the Rustic

Zhang

Stopping by the Aranya of the Late Venerable

Rong

Heart-held Thoughts in the Early Cold, On the Jiang

I Set a Time with an Aged Gardener to Plant

Melons under South Mountain

Service Manager Pei Pays Me a Visit ........... 420

New Year's Eve .......................... 420

Grieving for the Abbot of Beyond-the-Clouds

Abbey on Mount Xian

For Impromptu Composition I Draw the

Topic "Fair and Well-favored, the Lady in the

Tower"

Springtime Complaint ....................... 424

Sentiments from the Women's Quarters ........ 426

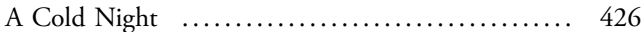

A Lovely Woman Apportioning Incense ........ 428 


\section{Heptametric Regulated Verse}

4.52 登安陽城樓
4.53 歲除夜有懷
4.54 登萬歲樓
4.55 春情

\section{Pentametric Quatrains}

4.56 宿建德江

4.57 春曉

4.58 送朱大入秦

4.59 送友人之京

4.60 初下浙江舟中口號

4.61 醉後贈馬四

4.62 檀溪寻故人

4.63 同張將薊門看燈

4.64 峴山亭寄晉陵張 少府

4.65 口號贈王九

4.66 同儲十二洛陽道 中作

4.67 寻菊花潭主人不遇

4.68 張郎中梅園作

4.69 問舟子

4.70 揚子津望京口

4.71 北澗泛舟

4.72 洛中訪袁拾遗不遇

4.73 送張郎中遷京

4.74 戲贈主人
Ascending a High Loft on the Anyang City-walls .. 430

Heart-held Thoughts at Night on New Year's Eve .. 432

Climbing the Tower of Myriad Years $\ldots . \ldots \ldots \ldots . .432$

Springtime Feelings ...................... 434

Passing the Night on the Jiande River $\ldots \ldots \ldots \ldots .434$

Spring Daybreak .......................... 436

Seeing Off Zhu (Eldest) On His Way Into Qin ... 436

Seeing Off a Friend to the Capital $\ldots . \ldots \ldots \ldots \ldots .436$

Upon First Descending the River Zhe, Composed

Aloud on the Boat ........................ 438

After Drinking Too Much; For Ma (Four) ...... 438

Seeking an Old Friend at Sandalwood Stream .... 440

To Go With Zhang's "Tending a Lamp in Jimen" ................................. 440

From the Mount Xian Pavilion; Sent to District

Constable Zhang of Jinling $\ldots \ldots \ldots \ldots \ldots \ldots \ldots . . \ldots 42$

Composed Aloud; For Wang (Nine) $\ldots \ldots \ldots \ldots \ldots .442$

To Go With Chu (Twelve)'s Poem "Composed on the Streets of Luoyang" ...................... 444

Seeking the Master of Chrysanthemum Blossom

Tarn, But Not Meeting Him $\ldots . . \ldots \ldots \ldots \ldots . . . . .444$

Composed at the Prunus Garden of Director

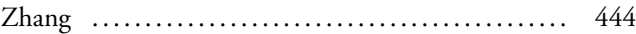

Inquiring of the Boatman $\ldots . . \ldots \ldots \ldots \ldots \ldots . . . \ldots 46$

At the Yangzi Ford, Looking Off at Jingkou ...... 446

Boating on the North Branch ................ 446

In Luoyang, Calling on Reminder Yuan But Not

Meeting Him $\ldots \ldots \ldots \ldots \ldots \ldots \ldots \ldots \ldots \ldots . . . \ldots 48$

Seeing Off Director Zhang on His Transfer to the

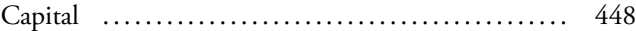

For My Host, in Fun $\ldots \ldots \ldots \ldots \ldots \ldots \ldots \ldots . . \ldots 48$

\section{Heptametric Quatrains}

4.75 過融上人蘭若 Stopping by the Aranya of His Eminence Rong ... 450

4.76 涼州詞二首, 其一 Liangzhou Lyric, No. 1 of 2 ................... 450

4.77 涼州詞二首, 其二 Liangzhou Lyric, No. 2 of 2 .................. 452

4.78 越中送張少府歸 In Yue, Seeing Off District Constable Zhang 秦中 Returning to Qin

4.79 濟江問同舟人 Crossing the River, Inquiring of a Fellow

Boatman .............................. 452

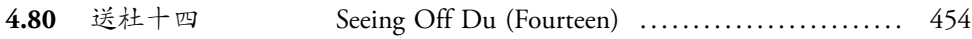




\section{Book 5}

\section{Uncollected Poems}

5.1 長樂宫

The Palace of Lasting Happiness $\ldots \ldots \ldots \ldots \ldots \ldots \quad 458$

5.2 渡揚子江

5.3 清明即事

5.4 初秋

5.5 白石灘

Crossing the Jiang at Yangzi

On Qingming Day, a Topic of the Moment ...... 460

Earliest Autumn ............................. 462

White Rock Rapids ........................ 462

\section{Unattached Verses}

5.6 微雲淡河漢

5.7 北關鿷天子

Wispy clouds pale the He and Han above ... .... 464

At the north pylons I bid farewell to the Son of

Heaven ................................. 464

Selected Bibliography..................................... 467

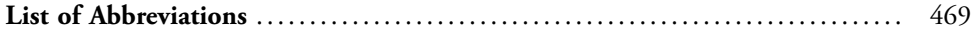

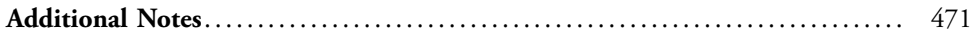

